Plankton Benthos Res 5(4): 136-143, 2010

\title{
Determining optimal temperature and salinity of Lucifer (Dendrobranchiata: Sergestoidea: Luciferidae) based on field data from the East China Sea
}

\author{
ZHAO L. XU* \\ East China Sea Fisheries Research Institute, Chinese Academy of Fisheries Sciences, 300 Jungong Road, Shanghai 200090, P. R. \\ China
}

Received 26 December 2007; Accepted 26 August 2010

\begin{abstract}
Distribution patterns and abundance of the epiplanktonic shrimp Lucifer were examined in the East China Sea $\left(23^{\circ} 30^{\prime}-33^{\circ} \mathrm{N}, 118^{\circ} 30^{\prime}-128^{\circ} \mathrm{E}\right)$, in relation to temperature and salinity. A total of 443 samples were collected from four seasonal surveys conducted between 1997 and 2000. The yield density model was used to predict optimal temperature (OT) and optimal salinity (OS) of four Lucifer species: Lucifer typus, L. hanseni, L. intermedius and L. penicillifer. Thereafter, their distribution patterns were determined. The results indicated that these species are the most abundant in summer. Lucifer typus, with OT of $28.0^{\circ} \mathrm{C}$ and OS of 33.8, is considered to be an oceanic tropic water species. The species is mainly found in the northern waters off Taiwan in summer and autumn. Lucifer hanseni, L. intermedius and L. penicillifer, with OTs of $26.4,28.0,27.4^{\circ} \mathrm{C}$ and OSs of 33.6, 33.4, 33.2, are off-shore subtropical water species. They are mainly distributed in the south off-shore the East China Sea and north of Taiwan.
\end{abstract}

Key words: East China Sea, Lucifer, optimal salinity, optimal temperature, zooplankton

\begin{abstract}
Introduction
Temperature and salinity are the most important factors related to the distribution of marine zooplankton (e.g. Belehràdek 1935, Kinne 1963, Heinle 1969, Huntley \& Lopez 1992). Populations of zooplankton reach their maxima at their respective optimal temperatures. Low temperatures can hinder maintenance or repair, while high temperatures can result in enzyme inactivation (Huey \& Kingsolver 1980). Salinity is also a fundamental factor in determining the distribution of zooplankton by affecting osmoregulation. Therefore, estimates of the optimal temperature (OT) and optimal salinity (OS), and thermal and saline tolerance ranges of species might help us to understand the relationship between zooplankton abundance and hydrological conditions.

Lucifer Thompson 1829 is a single genus belonging to the family Luciferidae of the order Decapoda (Burkenroad 1981, 1983). Seven species of Lucifer are widely distributed in tropical and subtropical waters (Bowman 1967, Omori 1976). All the species occur in the western North Pacific except for the Atlantic species L. faxoni Borradaile (Hashizume \& Omori 1998). Lucifer species are epiplank-
\end{abstract}

* Corresponding author: Zhao-li Xu; E-mail, xiaomin@sh163.net.cn tonic and are important in the diet of some fishes (e.g. Bowman \& McCain 1967, Huang \& Fang 1987). Previous studies on Lucifer in the East China Sea (ECS) mainly focused on taxonomy (Zheng 1954, Tsai \& Cheng 1965, Cai 1986). Less attention was paid to quantitative analyses of the population distributions (Chen et al. 1978, 1980, Meng et al. 1987, Bai 1990). According to Xu (2005a, b, c), Lucifer species were most abundant in summer and in the southern part of the ECS and inshore waters of the Taiwan Strait.

The OT and OS of zooplankton species have been measured mainly under laboratory conditions (e.g. Lyster 1965, Roddie et al. 1984, Uye 1988, 1990, Huntley \& Lopez 1992, Cervetto et al. 1999). For certain technical reasons, not all marine species can be cultured in the laboratory. Thus, I attempted to estimate the OT and OS of Lucifer using statistical models with field data in the ECS, and reveal how the hydrological factors affected Lucifer's distribution.

\section{Materials and Methods}

\section{Sample collection and analysis}

Figure 1 shows the study area. The samples were collected from the ECS $\left(23^{\circ} 30^{\prime}-33^{\circ} 00^{\prime} \mathrm{N}, 118^{\circ} 30^{\prime}-\right.$ 


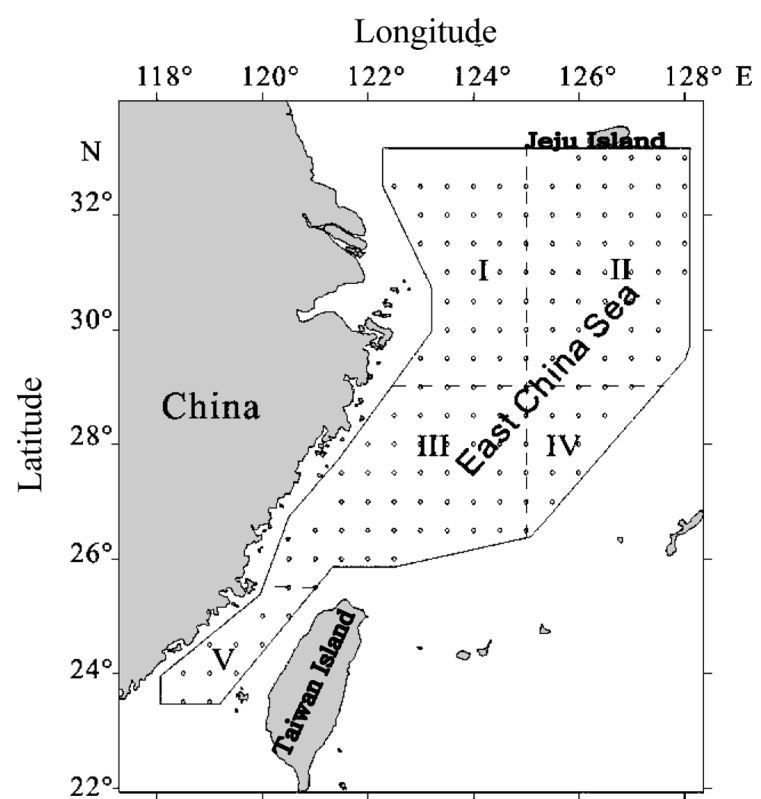

Fig. 1. Map of the study area. In the map, the dots indicate the location of sampling stations, which could be divided into five zones, zone I-north near-shore; zone II-north off-shore; zone IIIsouth near-shore; zone IV-south off-shore and zone V-Taiwan Strait.

$128^{\circ} 00^{\prime} \mathrm{E}$ ). Four seasonal surveys were conducted separately in the spring of 1998 (from March to May), the summer of 1999 (from June to August), the autumn of 1997 (from October to November) and the winter of 2000 (from January to February). The study area was divided into 5 zones along $29^{\circ} 30^{\prime} \mathrm{N}, 25^{\circ} 30^{\prime} \mathrm{N}$ and $125^{\circ} 00^{\prime} \mathrm{E}$, since their hydrographic conditions are clearly different from each other (Fishery Bureau of Ministry of Agriculture 1987). The five zones are zone I-north nearshore $\left(29^{\circ} 30^{\prime}-33^{\circ} 00^{\prime} \mathrm{N}\right.$, $\left.122^{\circ} 30^{\prime}-125^{\circ} 00^{\prime} \mathrm{E}\right)$, zone II-north off-shore $\left(29^{\circ} 30^{\prime}-\right.$ $33^{\circ} 00^{\prime} \mathrm{N}, 125^{\circ} 00^{\prime}-128^{\circ} 00^{\prime} \mathrm{E}$ ), zone III-south nearshore $\left(25^{\circ} 30^{\prime}-29^{\circ} 30^{\prime} \mathrm{N}, 120^{\circ} 30^{\prime}-125^{\circ} 00^{\prime} \mathrm{E}\right)$, zone IV-south offshore $\left(25^{\circ} 30^{\prime}-29^{\circ} 30^{\prime} \mathrm{N}, 125^{\circ} 00^{\prime}-128^{\circ} 00^{\prime} \mathrm{E}\right)$ and zone Vthe Taiwan Strait $\left(23^{\circ} 30^{\prime}-25^{\circ} 30^{\prime} \mathrm{N}, 118^{\circ} 00^{\prime}-121^{\circ} 00^{\prime} \mathrm{E}\right)$ (Fig. 1).

A total of 443 samples, among them 128 samples in spring, 132 samples in summer, 110 samples in autumn, and 63 samples in winter, were collected during the surveys. Most of these samples were collected by vertical hauls with a standard large net (mouth diameter $80 \mathrm{~cm}$, mesh size $0.505 \mathrm{~mm}$ ) from the sea floor to the surface. In a few stations where water depth was more than $150 \mathrm{~m}$, the net was towed vertically from $150 \mathrm{~m}$ depth to the surface. A flow-meter was mounted in the center of the net mouth to measure the volume of water filtered. The samples were immediately fixed and preserved in seawater with $5 \%$ buffered formalin. The surface water salinity and temperature were monitored using a CTD (SBE-19: Laurel Industrial Company) during each sampling session.

In the laboratory, the adult individuals of each Lucifer species were sorted, identified and counted with the aid of a stereomicroscope. Abundance units are in indiv. $\mathrm{m}^{-3}$. Zone $\mathrm{V}$ was not sampled in winter for certain technical reasons.

\section{Data analysis}

The distributions of Lucifer species were determined by surface water temperature and surface water salinity, as Lucifer are mainly distributed in the surface water. In this paper, average distribution temperature (ADT) refers to the mean of surface water temperatures from all stations where Lucifer occurred. Average distribution salinity (ADS) was defined similarly to ADT. The optimal temperature (OT) and optimal salinity (OS) were calculated using the yield density model. The thermal range (TR) and salinity range (SR) were the ranges of temperature and salinity (max-min) respectively found in the habitat of each Lucifer species. The percentage of the abundance of a particular species compared to the total Lucifer abundance was indicated as the abundance percentage (AP).

The yield density model was first applied in an analysis of crop yield and density (Holliday 1960) and has been widely used since then (e.g. Hellis et al. 1999, Schabenberger \& Pierce 2001). Here, this empirical model was employed to reveal the relationship between specific Lucifer abundance $(y)$ and temperature or salinity $(x)$. The model was expressed by the following equation:

$$
y=\frac{1}{a+b x+c x^{2}}
$$

The Marquardt method (Marquardt 1963, SAS Institute Inc. 1996) was used to estimate the parameters $a, b$ and $c$ in Eq. 1. From the point view of ecology, the OT or OS is defined as the $x$ when $y$ reaches a maximum in Eq.1. To acquire the maximum, Eq. 1 should be taken as the origin of the following derivative equation:

$$
y^{\prime}=\frac{b+2 c x}{\left(a+b x+c x^{2}\right)^{2}}
$$

The $x$ corresponding to the maximal point of $y$ in Eq. 1 is expressed as the $x$ when $y^{\prime}=0$ in Eq. 2. According to Roll's theorem (Ghosh \& Haque 2004), Eq. 3 came from simplified Eq. 2 when $y^{\prime}=0$, that is:

$$
x=-\frac{b}{2 c}
$$

Up to this point, the OT and OS can be calculated from Eq. 3 when $b$ and $c$ can be estimated by the Marquardt method. For a detailed treatment of calculations and process, see Christensen (1996).

According to the synchronous data, chlorophyll $a$ at most of the sampling stations was $<0.5 \mathrm{mg} \mathrm{m}^{-3}$ throughout the study period (Zheng et al. 2003). Temperature and salinity are the two main key factors left to affect Lucifer distribu- 
Table 1. Seasonal average surface water temperature, thermal range, average surface water salinity and salinity range in different zones of the East China Sea.

\begin{tabular}{|c|c|c|c|c|c|c|c|}
\hline & & & zone I & zone II & zone III & zone IV & zone V \\
\hline \multirow{8}{*}{$\begin{array}{l}\text { surface water } \\
\text { temperature }\left({ }^{\circ} \mathrm{C}\right)\end{array}$} & \multirow{2}{*}{ spring } & average & 14.9 & 16.9 & 21.3 & 21.4 & 24.2 \\
\hline & & range & $14.7-15.2$ & $12.8-21.2$ & $16.1-25.6$ & $17.7-25.4$ & $22.4-25.9$ \\
\hline & \multirow{2}{*}{ summer } & average & 25.8 & 25.8 & 26.6 & 25.5 & 27.7 \\
\hline & & range & $23.0-27.0$ & $21.3-28.6$ & $24.3-28.0$ & $23.9-27.5$ & $26.6-28.4$ \\
\hline & \multirow{2}{*}{ autumn } & average & 23.4 & 23.9 & 22.8 & 24.5 & 21.9 \\
\hline & & range & $22.2-24.5$ & $22.7-24.9$ & $20.0-25.7$ & $23.3-25.5$ & $19.4-23.2$ \\
\hline & \multirow{2}{*}{ winter } & average & 14.2 & 17.4 & 18.4 & 19.9 & - \\
\hline & & range & $12.7-16.5$ & $13.5-20.3$ & $12.4-23.4$ & $16.7-22.7$ & - \\
\hline \multirow{8}{*}{$\begin{array}{l}\text { surface water } \\
\text { salinity }\end{array}$} & \multirow{2}{*}{ spring } & average & 31.7 & 34.0 & 31.4 & 33.5 & 31.9 \\
\hline & & range & $29.1-33.2$ & $32.0-34.8$ & $27.9-34.0$ & $32.4-34.4$ & $30.7-32.7$ \\
\hline & \multirow{2}{*}{ summer } & average & 29.6 & 32.5 & 33.5 & 33.5 & 33.7 \\
\hline & & range & $18.6-33.2$ & $29.8-33.7$ & $29.6-34.1$ & $32.7-34.1$ & $33.3-34.1$ \\
\hline & \multirow{2}{*}{ autumn } & average & 32.4 & 33.5 & 33.8 & 34.1 & 33.7 \\
\hline & & range & $28.6-33.6$ & $32.1-34.4$ & $31.4-34.8$ & $33.8-34.5$ & $31.5-34.6$ \\
\hline & \multirow{2}{*}{ winter } & average & 33.0 & 34.0 & 34.2 & 34.5 & - \\
\hline & & range & $31.8-34.5$ & $32.0-34.7$ & $32.3-34.6$ & $34.4-34.7$ & - \\
\hline
\end{tabular}

Table 2. Adaptive distribution temperature (ADT), thermal range (TR), adaptive distribution salinity (ADS), and salinity range (SR) in habitats of Lucifer species in the East China Sea.

\begin{tabular}{|c|c|c|c|c|c|c|}
\hline \multirow{2}{*}{ Species } & \multirow{2}{*}{ seasons } & \multirow{2}{*}{$N^{*}$} & \multicolumn{2}{|c|}{ surface water temperature $\left({ }^{\circ} \mathrm{C}\right)$} & \multicolumn{2}{|c|}{ surface water salinity } \\
\hline & & & $\mathrm{ADT} \pm \mathrm{SD}$ & TR & $\mathrm{ADS} \pm \mathrm{SD}$ & SR \\
\hline \multirow{5}{*}{ Lucifer intermedius } & spring & 54 & $20.7 \pm 3.1$ & $14.0-26.3$ & $32.6 \pm 1.6$ & $28.7-34.7$ \\
\hline & summer & 111 & $26.2 \pm 1.4$ & $21.3-28.6$ & $32.3 \pm 2.5$ & $18.6-34.1$ \\
\hline & autumn & 98 & $23.3 \pm 1.2$ & $19.4-25.7$ & $33.5 \pm 1.0$ & $28.6-34.8$ \\
\hline & winter & 30 & $17.7 \pm 2.9$ & $12.7-22.7$ & $34.0 \pm 0.9$ & $32.0-34.7$ \\
\hline & entire year & 293 & $23.4 \pm 3.4$ & $12.7-28.6$ & $32.9 \pm 1.9$ & $18.6-34.8$ \\
\hline \multirow{5}{*}{ L. hanseni } & spring & 20 & $22.4 \pm 2.5$ & $16.4-25.4$ & $32.4 \pm 1.6$ & $28.9-34.6$ \\
\hline & summer & 30 & $26.3 \pm 1.4$ & $23.1-28.2$ & $33.3 \pm 1.0$ & $29.6-34.1$ \\
\hline & autumn & 0 & - & - & - & - \\
\hline & winter & 17 & $18.7 \pm 3.1$ & $12.7-22.7$ & $34.2 \pm 0.7$ & $32.3-34.7$ \\
\hline & entire year & 67 & $23.1 \pm 3.9$ & $12.7-28.2$ & $33.3 \pm 1.2$ & $28.9-34.7$ \\
\hline \multirow{5}{*}{ L. penicillifer } & spring & 8 & $22.1 \pm 2.3$ & $18.1-25.2$ & $32.3 \pm 1.3$ & $30.4-34.2$ \\
\hline & summer & 46 & $26.8 \pm 1.2$ & $23.1-28.6$ & $33.4 \pm 0.7$ & $31.2-34.1$ \\
\hline & autumn & 0 & - & - & - & - \\
\hline & winter & 4 & $18.3 \pm 2.8$ & $14.3-21.1$ & $34.5 \pm 0.3$ & $34.2-34.7$ \\
\hline & entire year & 58 & $25.3 \pm 3.1$ & $14.3-28.6$ & $33.2 \pm 1.0$ & $30.4-34.7$ \\
\hline \multirow{5}{*}{ L. typus } & spring & 14 & $22.6 \pm 3.0$ & $17.6-25.9$ & $33.1 \pm 1.1$ & $31.0-34.6$ \\
\hline & summer & 23 & $26.6 \pm 1.2$ & $24.1-28.0$ & $33.4 \pm 1.0$ & $30.9-34.1$ \\
\hline & autumn & 4 & $24.7 \pm 1.0$ & $23.4-25.6$ & $33.6 \pm 0.3$ & $33.2-34.0$ \\
\hline & winter & 5 & $20.4 \pm 2.0$ & $19.1-23.4$ & $34.6 \pm 0.1$ & $34.5-34.6$ \\
\hline & entire year & 46 & $24.7 \pm 2.9$ & $17.6-28.0$ & $33.4 \pm 1.0$ & $30.9-34.6$ \\
\hline
\end{tabular}

Notes: $N^{*}$, number of sample where the species of Lucifer occurred; Lucifer chacei only occurred twice, at $16.6^{\circ} \mathrm{C}, 30.5$, and $22.7^{\circ} \mathrm{C}, 31.0$. 
tion in the sampling area.

\section{Results}

The investigations covered most of the area and four seasons of the ECS. The surface water temperature and salinity ranged from $9.2^{\circ}$ to $28.6^{\circ} \mathrm{C}$ and 18.6 to 34.9 respectively during the period. Hydrographic measures exhibited a seasonal pattern (Table 1). Average surface water temperature was the lowest in winter, and peaked in summer. Average surface water salinity was the highest in winter. The salinities in offshore waters (zones III, IV) were general higher than nearshore (zones I, II).

Five species of Lucifer were found in present study. However, as L. chacei Bowman, which is known to inhabit only coastal waters (Bowman 1967), has rarely been collected, it was not included in the present analysis. Among the remaining four species, the ADT of $L$. penicillifer Hansen $\left(25.3^{\circ} \mathrm{C}\right)$ was the highest, followed by L. typus $(\mathrm{H}$. Milne Edwards) $\left(24.7^{\circ} \mathrm{C}\right)$, L. intermedius Hansen $\left(23.4^{\circ} \mathrm{C}\right)$ and $L$. hanseni Nobili $\left(23.1^{\circ} \mathrm{C}\right.$ ) (Table 2). These species were mainly found in summer when the surface water temperature was the highest in the year (Table 2). The TRs of $L$. penicillifer and L. typus were narrower compared with those of L. hanseni and L. intermedius (Table 2, Fig. 2).

As to the salinity adaptations of Lucifer species, ADS of L. intermedius (32.9) was lower than those of L. typus (33.4), L. penicillifer (33.2) and L. hanseni, (33.3), particularly in summer (Table 2). Lucifer intermedium and $L$. hanseni were distributed over a wider salinity range than $L$. typus and L. penicillifer. Particularly L. intermedius occurred in waters of any salinity within the ECS (Table 2, Fig. 2).

Although these Lucifer species can tolerate wide salinity
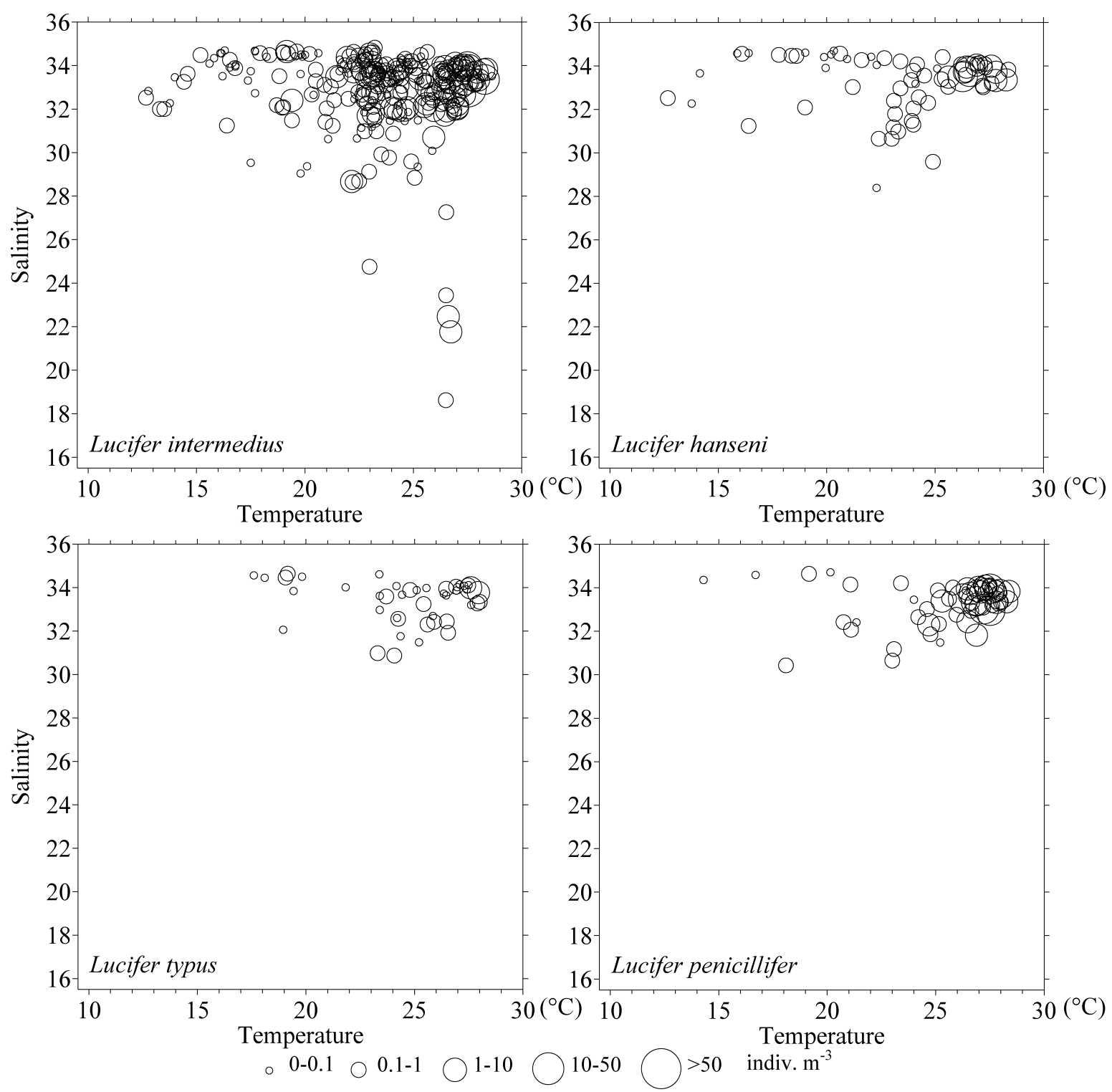

Fig. 2. Temperature and salinity conditions of the habitats of four species of Lucifer in the East China Sea. 
and temperature ranges, they were mainly distributed in waters with high temperatures and high salinities (Fig. 2). For example, even though $L$. penicillifer occurred in waters with a temperature of $14.3^{\circ} \mathrm{C}$; it was mainly distributed in waters warmer than $24.0^{\circ} \mathrm{C}$ (Fig. 2). Similarly, L. typus was collected at a salinity of 22.5 , yet it was mainly found at salinities higher than 30.5 (Fig. 2).

The OT and OS values of four Lucifer species are shown in Table 3. The OTs of $L$. penicillifer and L. typus were highest $\left(28.0^{\circ} \mathrm{C}\right)$, whereas only the OS of $L$. typus was the highest (33.8). Lucifer typus was mainly distributed in zone

Table 3. Optimal temperature and optimal salinity.

\begin{tabular}{lllrrc}
\hline \multicolumn{1}{c}{ species } & optimum & $R$ & $F$ & $p$ \\
\hline Lucifer intermedius & $t$ & $27.4^{\circ} \mathrm{C}$ & 0.33 & 25.64 & 0.0001 \\
& $S$ & 33.2 & 0.17 & 6.17 & 0.0023 \\
L. hanseni & $t$ & $26.4^{\circ} \mathrm{C}$ & 0.31 & 22.99 & 0.0001 \\
& $S$ & 33.6 & 0.20 & 9.06 & 0.0001 \\
L. penicillifer & $t$ & $28.0^{\circ} \mathrm{C}$ & 0.29 & 19.96 & 0.0001 \\
& $S$ & 33.4 & 0.15 & 4.92 & 0.0077 \\
L. typus & $t \mathrm{t}$ & $28.0^{\circ} \mathrm{C}$ & 0.42 & 46.98 & 0.0001 \\
& $S$ & 33.8 & 0.19 & 8.07 & 0.0004 \\
\hline
\end{tabular}

Notes: $t$ signifies surface water temperature $\left({ }^{\circ} \mathrm{C}\right) ; S$ signifies surface water salinity in the equation, $R$ is the goodness of fit of the model. $F$ and $p$ are the results of the $F$-test, which was used to analyze the statistical significance of the estimated parameters.
V during summer (Table 4). Lucifer hanseni was abundant in zone III. Both L. intermedius and L. penicillifer reached peak abundances in summer (Table 5). All the estimated OTs were in good accord with the field temperatures with the highest densities in the ECS (Fig. 2, Tables 3, 4).

The hyperhaline Taiwan Warm Current, strengthening northwards to zone III during summer, causes the high salinities in this zone, ranging from 33.5 to 34.0 (Zheng et al. 2003). High abundances of Lucifer species were located there, and the OSs of them were therefore thought to be reasonable. In short, the estimated OTs and OSs corresponded well with geographical distribution (Table 4) and seasonal abundance (Table 5) from the field data.

Lucifer intermedius, the predominant species, was widely distributed in the ECS all year round and was most abundant in summer. The remaining species, however, were mainly distributed in zones III, IV and V, which had high salinities, compared with zones I and II (Table 4).

In the graph showing the relationship between abundance and temperature or salinity, high abundance columns of $\mathrm{Lu}$ cifer were usually limited to narrow intervals for both temperature and salinity. Within these intervals, peak abundances were specifically around a certain value. For example, the graphs for L. intermedius and L. penicillifer showed peak abundance near a temperature about $27^{\circ} \mathrm{C}$ and salinity about 33.3 (Fig. 3).

Table 4. Geographical distribution of Lucifer in the East China Sea.

\begin{tabular}{|c|c|c|c|c|c|c|c|c|c|c|c|c|c|c|c|c|c|c|c|}
\hline \multirow{2}{*}{ Species } & \multicolumn{5}{|c|}{ spring } & \multicolumn{5}{|c|}{ summer } & \multicolumn{5}{|c|}{ autumn } & \multicolumn{4}{|c|}{ winter } \\
\hline & I & II & III & IV & $\mathrm{V}$ & I & II & III & IV & V & I & II & III & IV & V & $\mathrm{I}$ & II & III & IV \\
\hline L. intermedius & + & + & + & + & + & + & + & + & + & + & + & + & + & + & + & + & + & + & + \\
\hline L. hanseni & & + & + & + & + & + & & + & + & + & & & & & & + & + & + & + \\
\hline L. penicillifer & & & + & + & + & + & + & + & + & + & & & & & & & + & + & + \\
\hline L. typus & & + & + & + & + & + & + & + & + & + & & + & + & & & & + & + & \\
\hline L. chacei & & & + & & + & & & & & & & & & & & & & & \\
\hline
\end{tabular}

Note: "+" means occurrence. I: the north near-shore, II: the north off-shore, III: the south near-shore, IV: the south off-shore, V: the Taiwan Strait.

Table 5. The average abundance of Lucifer in the East China Sea in different seasons.

\begin{tabular}{|c|c|c|c|c|c|c|c|c|}
\hline \multirow{2}{*}{ Species } & \multicolumn{2}{|c|}{ spring } & \multicolumn{2}{|c|}{ summer } & \multicolumn{2}{|c|}{ autumn } & \multicolumn{2}{|c|}{ winter } \\
\hline & $\mathrm{y}$ & AP & $\mathrm{y}$ & AP & $\mathrm{y}$ & $\mathrm{AP}$ & $\mathrm{y}$ & $\mathrm{AP}$ \\
\hline L. intermedius & 0.1372 & 67.94 & 2.4470 & 57.68 & 0.5885 & 99.47 & 0.0948 & 62.92 \\
\hline L. hanseni & 0.0360 & 17.81 & 0.3711 & 8.75 & & & 0.0380 & 25.23 \\
\hline L. typus & 0.0098 & 4.84 & 0.0558 & 1.32 & 0.0032 & 0.53 & 0.0074 & 4.90 \\
\hline L. penicillifer & 0.0147 & 7.26 & 1.3688 & 32.26 & & & 0.0105 & 6.95 \\
\hline L. chacei & 0.0044 & 2.16 & & & & & & \\
\hline
\end{tabular}

Note: $y$ is the average abundance (indiv. $\mathrm{m}^{-3}$ ) in a season; AP refers to the percentage of the abundance of a particular species compared to the total Lucifer abundance. 

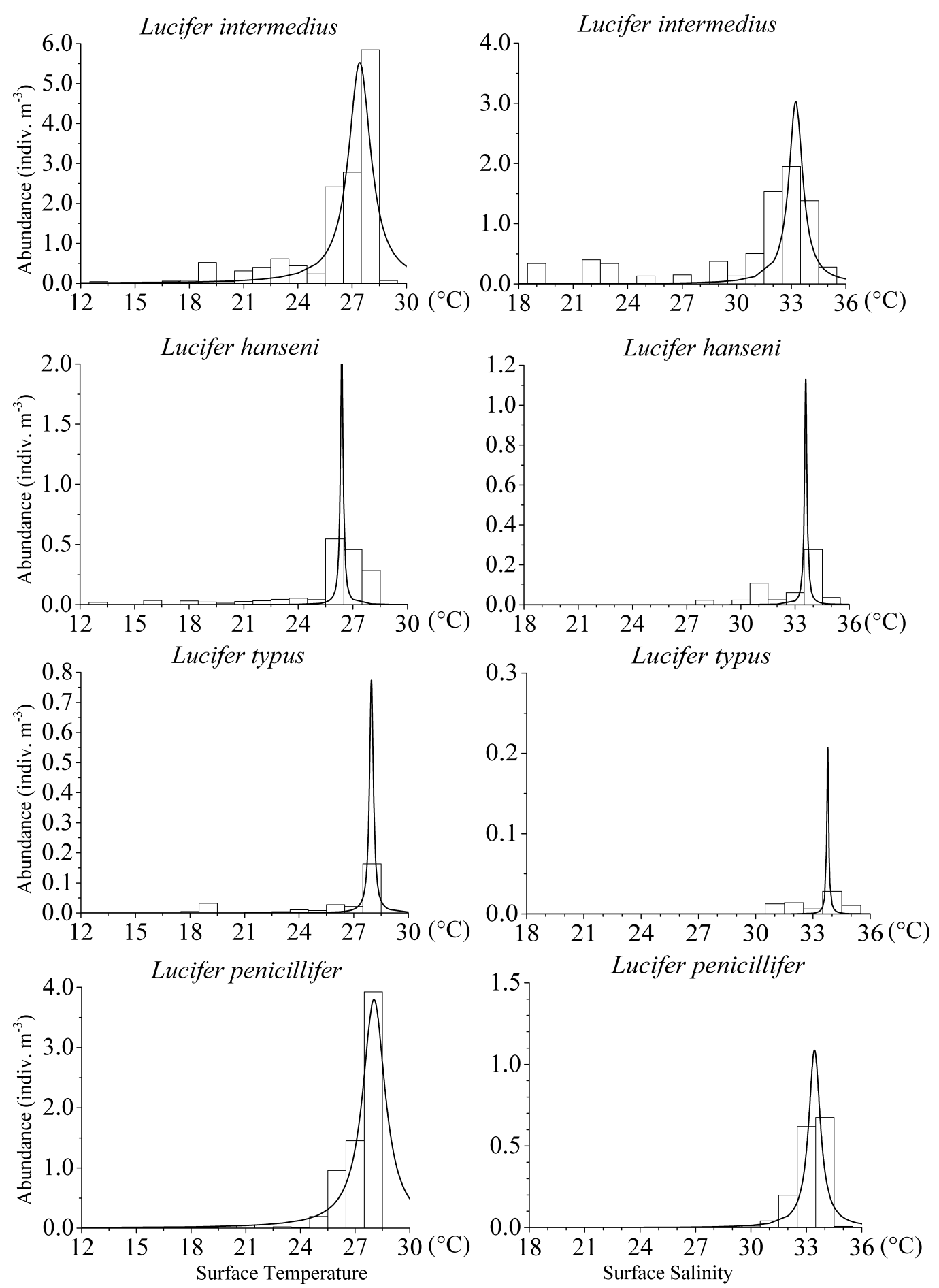

Fig. 3. Relationship between Lucifer species abundance and surface water temperature or salinity. The yield density model for each species is represented by the solid line.

\section{Discussion}

According to the principle of environmental biology, OT or OS should be the temperature or salinity at which populations can thrive and attain maximal abundance (Uye 1988, Lalli \& Parsons 1997, Shen \& Shi 2002). To ensure data authenticity, the sampled data need to include a wide range of temperatures and salinities from different seasons and zones (Hubert 2003). The data used in this study were collected from hundreds of stations all over the ECS in four seasons; a large scale area ranging from tropic to temperate water areas and from nearshore where coastal waters dominated to off-shore where warm currents dominated. The water temperature ranged from $9.2^{\circ}$ to $28.6^{\circ} \mathrm{C}$ and the 
salinity from 18.6 to 34.9 . The average surface water temperature was highest in summer and lowest in winter (Zheng et al. 2003). Spatially, the surface water temperature of zones III, IV and V was higher than that in zones I and II.

Based on the hydrographical features of the ECS, Shen \& Shi (2002) divided marine species into the following ecological groups: subtropical species with an OT from $20^{\circ}$ to $25^{\circ} \mathrm{C}$ and tropical species, with an OT over $25^{\circ} \mathrm{C}$. However, with respect to the salinity adaptations, Lucifer species may also be divided into off-shore species with an OS from 32 to 34, and oceanic species with an OS over 34. Thus, in the ECS, the off-shore species are mainly distributed in mixed waters; whereas oceanic species are mainly distributed in the waters affected by warm currents, particular the Kuroshio Current.

Lucifer typus, L. hanseni, L. intermedius, and L. penicillifer are all eurytherms. This is because their TRs are all greater than $10^{\circ} \mathrm{C}$ (Table 2) and all these species are distributed widely from the Yellow Sea to the South China Sea (Huang 1994), the western Pacific Ocean (Hashizume \& Omori 1998), and the Indian Ocean (Karuppasamy et al. 2006). As to salinity tolerances, Lucifer species, however, could be divided into two different ecological groups. $\mathrm{Lu}$ cifer typus and L. penicillifer are considered stenohaline species (Table 2), whereas L. intermedius and L. hanseni are considered euryhaline (Table 2).

In conclusion, both L. intermedius and L. penicillifer are subtropical off-shore species with adaptation to high temperatures. They were abundant in zones II-IV, but rarely found in zone I (Table 4). Their highest abundances were mainly found in waters with high temperatures, particular in summer (Figs 2, 3, Table 5). Lucifer hanseni was abundant in zones III-IV, by high salinity and high temperature compared with zones I-II. In summer, the species was widely distributed from nearshore to offshore. Although it was also collected in the coastal waters, bays or estuaries (Lin et al. 1998, Tan et al. 2004, Zhou \& Xu 2009), yet $L$. hanseni was most abundant in the south nearshore and south off-shore of the ECS in summer (Xu 2005c). Thus, the species was thought to be an off-shore subtropical species. Lucifer typus is considered to be an oceanic tropical species within the ECS. According to Xu (2005c), during summer its area of highest abundance lay south of $26^{\circ} 30^{\prime} \mathrm{N}$, where the Kuroshio and Taiwan Warm Currents prevail. In winter and spring, this species was found in zone II where it was influenced profoundly by the Kuroshio Current and Tsushima Current (Su 2001). According to studies from the NW Pacific, the species is considered to be an oceanic species that is mainly distributed in waters influenced by the Kuroshio Current (Omori 1976, Ma \& Song 1992, Hashizume \& Omori 1998). Lucifer typus was also abundant in the tropical water of the Indian Ocean (Roger 1993, Karuppasamy et al. 2006).

By employing empirical models and field data, an attempt was made in this article to reveal the relationship be- tween the OT or OS of Lucifer species and their distribution. Is only a pilot, and obviously further work is needed. For example, by analyzing the curves of empirical models, the eury- or steno-thermal adaptations of the species might also be determined. The analysis of OT or OS using field data, with a proper reification through laboratory work, will enrich our understanding of species-environment relationships.

\section{Acknowledgements}

The study was funded by the Major Research Plan of the National Natural Science Foundation of China, under contract No. 90511005 . Thanks to Chen Yuan-quan for providing hydrologic data. I also express gratitude to He De-hua, Yang Guan-min and Yang Yuan-li, the staff from the Second Institute of Oceanography, SOA, for their help in sample processing. Special thanks to Shen Xiao-min for his insightful suggestions and great efforts in the preparation of the manuscript. Also, I thank Zhu Jing from the Department of Biological Sciences, Florida Institute of Technology, U.S.A., for the final revision of the manuscript.

\section{References}

Bai HP (1990) Zooplankton in coastal zone of northern Zhejiang. Trans Chinese Crust Soc 2: 79-88. (in Chinese)

Belehràdek J (1935) Temperature and Living Matter. Protoplasma Monograph (8), Borntaeger, Berlin, 277 pp.

Bowman TH (1967) The planktonic shrimp Lucifer chacei sp. nov. (Sergestinae: Luciferinae), the Pacific twin of the Atlantic Lucifer faxoni. Pac Sci 21: 266-271.

Bowman TE, McCain JC (1967) Distribution of the planktonic shrimp, Lucifer, in the Western North Atlantic. Bull Mar Sci 17: 660-671.

Burkenroad MD (1981) The higher taxonomy and evolution of Decapoda (Crusteacea). Trans San Diego Soc Nat Hist 19(17): 251-268.

Burkenroad MD (1983) Natural classification of Dendrobranchiata, with a key to recent genera. In: Crustacean Phylogeny. Crustacean (ed Schram ER). Issues 1, A A Bakelma, Rotterdam, pp. 279-290.

Cai BJ (1986) Constituent, size and sexual ratio of Lucifer in Xiamen Harbour. J Oceanogr Taiwan Strait 5(2): 194-196. (in Chinese with English abstract)

Cervetto G, Gaudy R, Pagano M (1999) Influence of salinity on the distribution of Acartia tonsa (Copepoda, Calanoida). J Exp Mar Biol Ecol 239: 33-45.

Chen QC, Chen YQ, Hu YZ (1980) Preliminary study on the planktonic communities in the southern Yellow Sea and the East China Sea. Acta Oceanol Sin 2(2): 149-157. (in Chinese with English abstract)

Chen QC, Zhang GX, Chen BY (1978) Characteristics of zooplankton in Xisha and Zhongsha archipelago and adjacent waters. In: Report of halobios survey in Xisha and Zhongsha archipelago of China. Scientific Press, Beijing, pp. 81-84. (in Chinese) 
Christensen R (1996) Analysis of Variance, Design and Regression: Applied Statistical Methods. Chapman and Hall, New York, pp. 391-408, 414-432.

Fishery Bureau of Ministry of Agriculture (1987) Investigation and Division of Fisheries Resources of the East China Sea. East China Normal University Press, Shanghai, $661 \mathrm{pp}$.

Ghosh JD, Haque MA (2004) How to learn calculus of one variable, Vol. I. New Age International Publishers, New Delhi, pp. 871-805.

Hashizume K, Omori M (1998) Distribution of warm epiplanktonic shrimp of the genus Lucifer (Decapoda: Dendrobranchiata: Sergestinae) in the northwestern Pacific Ocean with special reference to their adaptive features. IOC (Intergov Oceanogr Comm) Workshop Rep 142: 156-162.

Heinle DR (1969) Temperature and zooplankton. Chesap Sci 10: 186-209.

Hellis RH, Salahi M, Jones SA (1999) Yield-density equations can be extended to quantify the effect of applied nitrogen and cultivar on wheat grain yield. Ann Appl Biol 134: 347-352.

Holliday R (1960) Plant population and crop yield. Field Crop Abstracts 13: 159-167.

Huang MZ, Fang JH (1987) Distribution of Lucifer and its relation of fishery in Taiwan Strait and its adjacent area. J Oceanogr Taiwan Strait 6: 107-113. (in Chinese with English abstract)

Huang ZG (1994) Marine Species and Their Distribution in China's Sea. Ocean Press, Beijing, 764 pp. (in Chinese)

Hubert G (2003) Statistical Analysis of Management Data. Kluwer Academic Publisher, Dordrecht, pp. 1-54.

Huey RB, Kingsolver JG. 1980. Evolution of thermal sensitivity of ectotherm performance. Trends Ecol Evol 4: 131-135.

Huntley ME, Lopez MDG (1992) Temperature-dependent production of marine copepods: A global synthesis. Am Nat 140: 201-242.

Karuppasamy PK, Menon NG, Nair KKC, Achuthankutty CT (2006) Distribution and abundance of pelagic shrimps from the deep scattering layer of the eastern Arabian Sea. J Shellfish Res 25: $1013-1019$.

Kinne O (1963) The effects of temperature and salinity on marine and brackish water animals. I. temperature. Oceanogr Mar Biol Annu Rev 1: 301-340.

Lalli CM, Parsons TR (1997) Biological Oceanography: An Introduction (2nd edition). Butterworth-Heinemann, Oxford, 406 pp.

Lin JH, Chen RX, Lin M, Dai YY (1998) Distribution of zooplankton in Sansha Bay and its comparison with that in Xinghua Bay and Dongshan Bay. J Oceanogr Taiwan Strait 7: 426-432. (in Chinese with English abstract)

Lyster IHJ (1965) The salinity tolerance of Polychaete larvae. J Anim Ecol 34: 517-527.

Ma ZD, Song QY (1992) A preliminary study on the Lucifer from the Kuroshio Region of the East China Sea. J Oceanogr Huanghai \& Bohai Sea 10: 53-62. (in Chinese with English abstract)

Marquardt DW (1963) An algorithm for least-squares estimation of nonlinear inequalities. SIAM J Appl Math 11: 431-441.

Meng F, Mao XH, Yu JL, Zhang XL, Huang FP, Li RX (1987) On the composition and distribution of zooplankton species in the coastal waters off Jiangsu province. Acta Ecol Sin 7(3): 256-266. (in Chinese with English abstract)

Omori M (1976) Distribution of warm water epiplanktonic shrimps of the genera Lucifer and Acetes (Macrura, Penaeidea, Sergestidae). In: Proc Sym Water Zoopl (Special Pulication of National Institiute of Oceanography): 1-12. (UNESCO, Goa).

Roddie BD, Leakey RJG, Berry AJ (1984) Salinity-temperature tolerance and osmoregulation in Eurytemora affinis (Poppe) (Copepoda: Calanoida) in relation to its distribution in the zooplankton of the upper reaches of the Forth Estuary. J Exp Mar Biol Ecol 77: 191-211.

Roger C (1993) The plankton of the tropical western Indian ocean as a biomass indirectly supporting surface tunas (yellowfin, Thunnus albacares and skipjack, Katsuwonus pelamis). Environ Biol Fish 39: 161-172

SAS Institute Inc. (1996) SAS/STAT Software: Changes and Enhancements through Release 6.12. SAS Institute Inc., Cary, North Carolina.

Schabenberger O, Pierce FJ (2001) Contemporary Statistical Models for the Plant and Soil Sciences. CRC Press, Clevelan, $738 \mathrm{pp}$.

Shen GY, Shi BZ (2002) Marine Ecology. Science Press, Beijing, 446 pp. (in Chinese)

$\mathrm{Su}$ JL (2001) A review of circulation dynamics of the coastal oceans near China. Acta Oceanol Sin 23(3): 1-16. (in Chinese)

Tan YH, Huang LM, Chen QC, Huang XP (2004) Seasonal variation in zooplankton composition and grazing impact on phytoplankton standing stock in the Pearl River Estuary, China. Cont Shelf Res 24: 1949-1968.

Tsai PC, Cheng C (1965) Notes on the Luciferinae of the South eastern coast. J Xiamen Univ Nat Sci 12: 111-122. (in Chinese)

Uye S (1988) Temperature-dependent development and growth of Calanus sinicus (Copepoda: Calanoida) in the laboratory. Hydrobiologia 167/168: 285-293.

Uye S (1990) Temperature-dependent development and growth of planktonic copepods Paracalanus sp. in the laboratory. Bull Plankton Soc Japan (Special Vol): 627-636.

Xu ZL (2005a) Relationship between pelagic decapods and environmental factors in the East China Sea. J Fish Sci China 12: 614-620. (in Chinese with English abstract)

Xu ZL (2005b) Species composition and diversity of pelagic decapods in the East China Sea. Mar Environ Sci 29: 762-768. (in Chinese with English abstract)

$\mathrm{Xu}$ ZL (2005c) Study on the dominant species of pelagic decapods in the East China Sea and their ecological adaptability. J Fish China 29: 762-768 (in Chinese with English abstract)

Zheng YJ, Chen XZ, Chen JH, Wang YL, Shen XQ, Chen WZ, Li CS (2003) The Biological Resources and Environment in Continental Shelf of the East China Sea. Shanghai Science and Technology Press, Shanghai, pp. 30-65. (in Chinese)

Zheng Z (1954) Study on marine planktonic Crustacea in Xiamen harbor. Acta Sci Nat Univ Amoiensis 3: 1-12. (in Chinese)

Zhou XD, Xu ZL (2009) Ecological characteristics of the pelagic decapods in the Changjiang Estuary. J Fish China 33 (1): 30-36. (in Chinese with English abstract) 